\title{
JAWABAN SOAL UTS 2018/2019 MATA KULIAH HAKI
}

\section{Sulistyawati}

155100094

Fakultas Komputer, 448757160

sulistyawati.student@umitra.ac.id

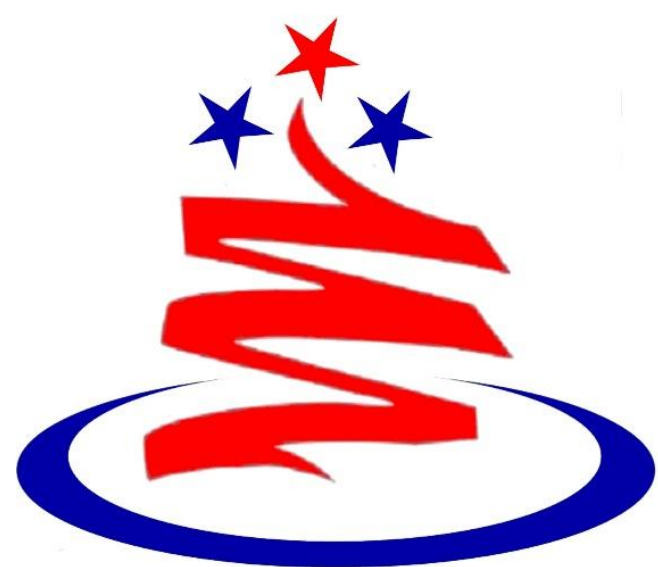

UnIVERSITAS IIITRA IIDORESIA 


\section{A. STUDI KASUS ( SK ) Pertanyaan Type C :}

Paparkan dan jelaskan produk knowledge/ produk tim anda (KP)

Jawaban :

\section{Hak paten EVO}

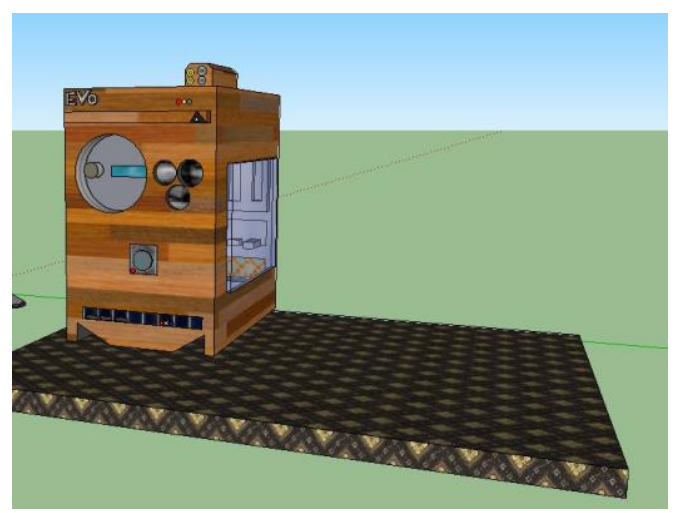

Memiliki hak paten dari "EVO" dan memiliki hak orisinil dari pemerintah republic Indonesia,

Evo berasal dari kata evolution yang memilki arti perkembangan.

Nama produk ini diambil dengan tujuan supaya CPU yang berkembang pada saat ini lebih canggih dan lebih unggul.

2. Rahasia dagang

- Evo memiliki garansi 2 tahun

- Mempunyai ketahanan yang kuat
- Tidak memiliki berat yang berlebihan

3. Spesifikasi

MERK : EVO

MODEL $\quad$ :EVO001

PROCESSOR : Intel ${ }^{\circledR}$ Core $^{\mathrm{TM}}$

i7 processor Extreme Edition

Memory $\quad$ : RAM 16 GB

HARDISK : $2 \mathrm{~TB}$

VGA Card : GeForce GTX

1060

POWER SUPPLY : $350 \mathrm{~W}$

BERAT $: 3 \mathrm{KG}$

Full HD, Bluetooth, WiFi, USB, HDMI, LAN.

\section{B. STUDI REFERENSI ( SP )} Pertanyaan Jenis B :

Jelaskan pasal pasal pendukung didalam hak atas kekayaan intelektual.

Jawaban : 
1. UNDANG-UNDANG

REPUBLIK INDONESIA NOMOR

13

TAHUN

2016

TENTANG

PATEN

DENGAN RAHMAT TUHAN

YANG MAHA ESA PRESIDEN

REPUBLIK INDONESIA,

Menimbang

Mengingat

a. bahwa paten merupakan kekayaan intelektual yang diberikan oleh negara kepada inventor atas hasil invensinya di bidang teknologi yang mempunyai peranan strategis dalam mendukung pembangunan bangsa dan memajukan kesejahteraan umum

b. bahwa perkembangan teknologi dalam berbagai bidang telah sedemikian pesat sehingga diperlukan peningkatan pelindungan bagi inventor dan pemegang paten

c. bahwa peningkatan pelindungan paten sangat penting bagi inventor dan pemegang paten karena dapat memotivasi inventor untuk meningkatkan hasil karya, baik secara kuantitas maupun kualitas untuk mendorong kesejahteraan bangsa dan negara serta menciptakan iklim usaha yang sehat

d. bahwa Undang-Undang Nomor 14 Tahun 2001 tentang Paten sudah tidak sesuai dengan perkembangan hukum, baik nasional maupun internasional sehingga perlu diganti

e. bahwa berdasarkan pertimbangan sebagaimana dimaksud dalam huruf a, huruf $b$, huruf $c$, dan huruf $d$, perlu membentuk Undang-Undang tentang Paten. Pasal 5 ayat (1), Pasal 20, Pasal

28C ayat (1), dan Pasal 33 Undang-Undang Dasar Negara Republik Indonesia Tahun 1945 Dengan PRESIDEN REPUBLIK INDONESIA

2. UU Nomor 28 Tahun 2014 tentang Hak Cipta

Peraturan Pemerintah Republik Indonesia Nomor 7 Tahun 1989 tentang Perubahan atas Peraturan Pemerintah Nomor 14 Tahun 1986 tentang Dewan 
Hak Cipta ditetapkan Tanggal 5 April 1989.

Peraturan Pemerintah Republik Indonesia Nomor 1 Tahun 1989 tentang Penterjemahan dan/atau Perbanyakan Ciptaan untuk Kepentingan Pendidikan, Ilmu Pengetahuan, Penelitian dan Pengembangan ditetapkan Tanggal 14 Januari 1989.

Peraturan Pemerintah Republik Indonesia Nomor 45 Tahun 2016 tentang Jenis Dan Tarif Atas Penerimaan Negara Bukan Pajak Yang Berlaku Pada Kementerian Hukum dan Hak Asasi Manusia

\section{STUDI PENALARAN ( SP )} Pertanyaan Kategori 3 :

Buatlah penjelasan secara detail produk blackberry dan beberapa bagian HAKI yang ikut serta bagiannya

Jawaban :

\section{Nama produk : Blackberry}

1. Hak paten :

Hak paten dari produk blackberry adalah mike lazaridis dan doug freigin. Mereka adalah orang kanada.
Sejarah singkat blackberry

produsen ponsel BlackBerry mengusung nama perusahaan Research In Motion ( RIM). Di akhir Januari 2013, Research In Motion membuat keputusan mengejutkan dengan mengganti nama perusahaan menjadi BlackBerry.Perusahaan itu akan dikenal dengan kode "BBRY" di Nasdaq, AS, dan "BB" di Toronto Stock Exchange, Kanada. BlackBerry kemudian berevolusi menjadi telepon genggam, dan tersohor karena fitur push mail dan aplikasi pesan instan BlackBerry Messenger semua jaringan operator seluler mengalami gangguan, namun jaringan BlackBerry tetap berjalan baik. Media massa di AS memuji kehebatan BlackBerry. Seorang Oprah Winfrey pun mengatakan pada 2003, BlackBerry adalah gadget favoritnya. BlackBerry, nama yang enak didengar, merepresentasikan desain ponsel yang kala itu selalu hadir dalam warna hitam. Tombol kecil pada papan ketik jadi ciri khas tersendiri. Nama BlackBerry lebih terkenal dibandingkan Research In Motion ataupun RIM. 


\section{REFERENSI}

7.0 University Of Mitra Indonesia.

Retrieved From Osf.Io/Pbrn9.

[1] A. S. Putra And O. M. Febriani, "Knowledge Management Online Application In Pdam Lampung Province," In Prosiding International Conference On Information Technology And Business (Icitb), 2018, Pp. 181-187.

[2] A. S. Putra, O. M. Febriani, And

B. Bachry, "Implementasi Genetic Fuzzy System Untuk Mengidentifikasi Hasil Curian Kendaraan Bermotor Di Polda Lampung," J. Sist. Inf. Dan Manaj. Basis Data, Vol. 1, No.1, Pp. 21-30, 2018.

[3] O. M. Febriani And A. S. Putra, "Sistem Informasi Monitoring Inventori Barang Pada Balai Riset Standardisasi Industri Bandar Lampung," J. Inform., Vol. 13, No. 1, Pp. 90-98, 2014.

[4] Putra, Arie Setya. \&quot;2018 Artikel Struktur Data, Audit Dan Jaringan Komputer.\&quot; (2018).

[5] Putra, A. S. (2018, July 17). Paperplain Fundamental Create Application With Borland Delphi 